\title{
REKONSTRUKSI PARADIGMA HUKUM HAKIM DALAM PENANGANAN KASUS TINDAK PIDANA KORUPSI DI PENGADILAN TIPIKOR MAKASSAR
}

\author{
Oleh:
}

\author{
Andi Irfan \\ Fakultas Hukum Universitas Muhammadiyah Kupang \\ E-mail: irfan_justiciable@yahoo.com
}

\begin{abstract}
The purpose of this research is to know the true meaning of judges at the Corruption Court Makassar against corruption and the implications of the true meaning of the verdict. This research also aims to know the reconstruction efforts of paradigm law judges in order to realize the decision of the law the fair which is based on the principles of progressive law. This research uses the socio-legal legal approach with qualitative data types. Data analysis with interactive model. Data collection technique that is used is the interview and documentation. The result research showed that in practice in the Corruption Court Makassar, paradigm of law judges with character positivistic still dominate the paradigm of judges in interpreting the terms of legislation. The implication many corruption cases that are submitted to the Corruption Court Makassar disconnected free and was sentenced for criminal sanction relatively. Reconstruction efforts of paradigm law judges can be done with the way the values of the paradigm of the old law need to be criticized, updated, and/or replaced with the values of the new legal paradigm that progressive and responsive. The reconstruction can include: (i) reconstruction of the way of thinking of progressive law; (ii) reconstruction method of interpretation of progressive law; and (iii) the reconstruction of professional ethics of judges progressive in running the law.
\end{abstract}

Keywords: Reconstruction, Legal Paradigm, Corruption

\begin{abstract}
Abstrak
Tujuan penelitian ini adalah untuk mengetahui pemaknaan hakim Tipikor Makassar terhadap korupsi dan implikasi pemaknaan tersebut terhadap putusan. Penelitian ini juga bertujuan untuk mengetahui upaya rekonstruksi paradigma hukum hakim dalam rangka mewujudkan putusan hukum yang adil, yang didasarkan pada prinsip-prinsip hukum progresif. Penelitian ini menggunakan pendekatan sosio-legal dengan jenis data kualitatif. Analisis data dengan model interaktif. Teknik pengumpulan data yang digunakan adalah wawancara dan dokumentasi. Hasil penelitian ini menunjukkan bahwa dalam praktik di Pengadilan Tipikor Makassar, paradigma hukum hakim dengan karakter positivistik masih mendominasi paradigma hakim dalam menafsirkan ketentuan perundangundangan. Implikasinya banyak kasus korupsi yang diajukan ke pengadilan Tipikor Makassar diputus bebas dan dijatuhi sanksi pidana yang relatif ringan. Upaya rekonstruksi paradigma hukum hakim dapat dilakukan dengan cara nilainilai paradigma hukum lama perlu dikritisi, diperbarui, dan/atau diganti dengan nilai-nilai paradigma hukum baru yang progresif dan responsif. Rekonstruksi
\end{abstract}


tersebut dapat meliputi: (i) rekonstruksi cara berfikir hukum yang progresif; (ii) rekonstruksi metode penafsiran hukum yang progresif; dan (iii) rekonstruksi etika profesi hakim yang progresif dalam menjalankan hukum.

Kata kunci: Rekonstruksi, Paradigma Hukum, Korupsi

\section{A. PENDAHULUAN}

Dalam ikhtiar mencegah, memberantas, dan membasmi tindak pidana korupsi di Indonesia, entah sudah berbagai badan dan lembaga dibentuk mulai dari sejak masa orde lama, orde baru, masa reformasi, dan bahkan pasca reformasi sekarang ini, namun hasilnya belum memadai. Berbagai peraturan perundang-undangan pun telah disahkan sebagai sarana menjerat para pelaku korupsi. ${ }^{1}$ Khusus pada pasca reformasi sekarang ini, yakni sejak tahun 2006, dengan dibentuknya lembaga pengadilan Tindak Pidana Korupsi (Tipikor) di berbagai daerah melalui putusan judicial review Mahkamah Konstitusi atas Pasal 53 UU No. 30 Tahun 2002 tentang Komisi Pemberantasan Korupsi, dengan nomor putusan No. 012-016-019/PPU-IV/2006, Indonesia mempunyai mekanisme untuk melakukan pengusutan dan penuntutan terhadap kasus-kasus korupsi yang terjadi di daerah. ${ }^{2}$

Hadirnya mekanisme tersebut membuka peluang dihadapkannya para pelaku korupsi yang sebelumnya menikmati imunitas ke depan pengadilan. Sejak saat itu, serangkaian upaya penyelidikan atas kasus-kasus yang diduga mengandung unsur muatan korupsi yang terjadi di berbagai daerah mulai dilakukan. Salah satu daerah di mana dibentuk pengadilan Tipikor adalah di Kota Makassar.

Pada awal terbentuknya lembaga pengadilan Tipikor di berbagai daerah seakan meniupkan angin harapan di tengah maraknya kasus-kasus korupsi di daerah yang sebelumnya begitu sulit untuk dilakukan pengusutan. Namun seiring perjalanannya lembaga ini pun tidak sepi dari berbagai sorotan, kritik tajam, serta seruan pembubaran yang dilontarkan oleh berbagai kalangan. Sorotan, kritik tajam, serta seruan pembubaran tersebut berkenaan dengan semakin markanya kasus-kasus korupsi yang diputus dengan sanksi pidana yang sangat ringan bahkan tidak sedikit kasus korupsi yang diputus bebas.

M. Nurul Irfan, 2011, Korupsi dalam Hukum Pidana Islam, Amzah, Jakarta, hlm. 9.

Ermansyah Djaja, 2010, Meredesain Pengadilan Tipikor: Implikasi Putusan MK No. 012-016019/PPU-IV/2006, Sinar Grafika, Jakarta, hlm. 3. 
Realitas empiris penanganan kasus-kasus korupsi oleh para hakim di Pengadilan Tindak Pidana Korupsi (Tipikor) menunjukkan fakta bahwa para hakim di lembaga peradilan tersebut cenderung menjatuhkan putusan dengan sanksi yang relatif ringan dan bahkan tidak jarang para hakim menjatuhkan vonis bebas (tidak bersalah) terhadap terdakwa kasus korupsi.

Menurut hemat penulis, untuk mengungkap makna-makna yang tersembunyi di balik tindakan hakim dalam membuat putusan tentang korupsi, maka akan sangat tepat jika penulis penempatkan fokus studi ini dalam domain "pradigma hukum hakim" dengan titik fokus kajian hukum progresif. Dengan demikian, dari hasil mengkaji putusan-putusan hakim, akan terungkap nilai-nilai, gagasan, cara pandang, keyakinan, dan pola perilaku hakim dalam menyusun putusan korupsi. Dari temuan-temuan studi ini nantinya, selanjutnya akan direfleksikan untuk merekonstruksi paradigma hukum hakim yang berbasis pada hukum progresif. Hukum progresif digunakan untuk memberikan perspektif baru dalam upaya menjawab persoalan yang dihadapi, sehingga akan dihasilkan putusan hakim yang adil, benar, bermanfaat, dan melindungi kepentingan masyarakat. Sehubungan dengan permasalahan hukum tersebut, maka akan ditelaah lebih lanjut pemaknaan hakim pengadilan Tipikor Makassar tentang korupsi dan implikasi pemaknaan tersebut pada putusan, serta upaya rekonstruksi paradigma hukum hakim dalam penanganan kasus tindak pidana korupsi.

\section{B. METODE PENELITIAN}

Studi ini termasuk jenis kajian deskriptif kualitatif yang bertitik tolak dari paradigma konstruktivisme. ${ }^{3}$ Asumsi dasar dari realitas yang dikaji merupakan hasil konstruksi mental para individu (hakim) yang bersifat subjektif dan beragam. Hukum di sini dimaksudkan sebagai putusan hakim yang bersifat simbolik yang memiliki makna sesuai presepsi, keyakinan, dan nilai yang dianut para hakim. Makna hukum tersebut tidak terlepas dari proses interaksi yang dilakukan hakim secara individu ataupun kelompok dengan lingkungannya. Hasil konstruksi mental

3 Terdapat empat paradigma yang dikenal dalam kegiatan penelitian, yaitu paradigma positivisme, post positivisme, kritikal teori, dan konstruktivisme. Pilihan paradigma ini akan berpengaruh pada perbedaan konsep, teori, asumsi, dan kategori tertentu yang melatarbelakangi studi tersebut dan oleh karenanya berujung pada perbedaan hasil kesimpulan yang diambil. Baca Agus Salim (Penyunting), 2001, Teori dan Paradigma Penelitian Sosial (Pemikiran Norman K. Denzin dan Penerapannya), PT. Tiara Wacana, Yogyakarta, hlm. 33-34. 
tersebut juga tidak terlepas dari social setting, yaitu institusi atau lembaga di mana hakim tersebut bekerja.

Dalam konteks kajian hukum, studi ini termasuk dalam tradisi kajian hukum empiris dengan pendekatan sosiolegal (socio-legal approach). ${ }^{4}$ Objek yang dikaji adalah hukum yang dikonsepkan sebagai simbol yang penuh makna sebagai hasil konstruksi mental manusia (hakim) yang termanifestasikan dalam bentuk putusanputusan kasus korupsi. Untuk mengungkap realitas objek tersebut digunakan teori hermeneutika hukum. Teori ini difungsikan untuk memahami makna-makna hukum secara emik, sebagaimana dikonstruksi oleh komunitas hakim yang dapat dipahami melalui jalan penafsiran (interpretation).

Apabila mengacu pada metode penelitian dari Peter M. Marzuki, pendekatan penelitian yang dipilih pada studi ini termasuk dalam kategori pendekatan konseptual. Pendekatan ini dilakukan manakala peneliti tidak beranjak dari aturan hukum. Hal itu dilakukan karena memang belum atau tidak ada aturan hukum untuk masalah yang dihadapi. Oleh karena itu, untuk membangun argumentasi hukum peneliti harus membangun suatu konsep untuk dijadikan acuan di dalam penelitian. ${ }^{5}$

Penelitian ini dilaksanakan di Kota Makassar khususnya di Pengadilan Tindak Pidana Korupsi pada Pengadilan Negeri Makassar. Data yang diambil berupa data premier dan data sekunder yang berupa hasil wawancara dan dokument putusan, serta data tentang jumlah perkara yang telah diputus oleh pengadilan Tipikor. Sinkronisasi antara data premier dan data sekunder kemudian digunakan untuk menganalisis upaya rekonstruksi paradigma hukum hakim berbasis hukum progresif. Analsis data menggunakan analisis data kualitatif mengikuti model interaktif dari Mattew B. Miles dan A. Michael Haberman yang terdiri dari kegiatan pengumpulan data, reduksi data, penyajian data, dan penarikan simpulan/verifikasi.

Syahruddin Nawi, 2013, Penelitian Hukum Normatif versus Penelitian Hukum Empiris, Cetakan Pertama, Umitoha Ukhuwa Grafika, Makassar, hlm. 14.

5 Peter M. Marzuki, 2005, Penelitian Hukum, Edisi Revisi, Kencana Prenamedia Group, Jakarta, hlm. 177. 


\section{PEMBAHASAN}

1. Gambaran Umum Penanganan Korupsi di Pengadilan Tipikor Makassar

Untuk mengetahui kinerja hakim dalam menangani perkara korupsi di pengadilan Tipikor Makassar, berikut dipaparkan hasil statistik penanganan perkara sejak tahun 2011 sampai dengan tahun 2016.

Tabel 1

Penanganan Perkara Korupsi yang Diperiksa dan Diputus

Pengadilan Tipikor Makassar Tahun 2011-2016

\begin{tabular}{cccc}
\hline Tahun & Jumlah Perkara & $\begin{array}{c}\text { Diputus } \\
\text { Tidak Bersalah (\%) }\end{array}$ & Diputus Bersalah (\%) \\
\hline 2011 & 67 & $2(2,98)$ & $65(97,02)$ \\
\hline 2012 & 86 & $1(1,17)$ & $85(98,83)$ \\
\hline 2013 & 119 & $-(0)$ & $119(100)$ \\
\hline 2014 & 105 & $2(1,90)$ & $103(98,10)$ \\
\hline 2015 & 98 & $4(4,09)$ & $94(95,91)$ \\
\hline 2016 & 32 & $3(9,37)$ & $29(90,63)$ \\
\hline Total & $\mathbf{5 0 7}$ & $\mathbf{1 2 ( 2 , 3 7 )}$ & $\mathbf{4 9 5}(\mathbf{9 7 , 6 3 )}$
\end{tabular}

Sumber: Data Sekunder Pengadilan Tipikor Makassar Tahun 2011-2016 yang diolah

Dari Tabel 1 tersebut dapat diketahui bahwa sejak berdirinya pengadilan Tipikor Makassar pada tahun 2011 sampai tahun 2016, pengadilan Tipikor Makassar telah berhasil menangani perkara korupsi sebanyak 507 perkara. Jika diperbandingkan antara perkara yang diputus tidak bersalah dan perkara yang diputus bersalah adalah 12 : 495 atau 2,37\% : 97,63\% dari total 507 perkara yang ditangani. Mencermati perbandingan tersebut, maka dapat dikatakan bahwa tren penjatuhan putusan tidak bersalah terhadap perkara korupsi di pengadilan Tipikor Makassar bersifat fluktuatif setiap tahunnya. Namun, kondisi yang mengejutkan terjadi pada tahun 2016, dalam jangka waktu baru dua bulan yakni sampai bulan Februari 2016, pengadilan Tipikor Makassar telah menjatuhkan 3 vonis tidak bersalah terhadap perkara korupsi. Ini berarti pada tahun 2016 ini terdapat tren negatif putusan pengadilan Tipikor jika dibandingkan dengan tahun-tahun sebelumnya.

Jika dilihat dari segi gradasi sanksi yang dijatuhkan terhadap perkara korupsi yang diperiksa oleh pengadilan Tipikor Makassar sejak berdirinya di 
tahun 2011 sampai tahun 2016, menunjukkan adanya kecenderungan peningkatan jumlah perkara yang diputus dengan vonis yang sangat ringan di setiap tahun. Berikut dipaparkan hasil statistik gradasi sanksi yang dijatuhkan oleh pengadilan Tipikor Makassar tahun 2011-2016.

Tabel 2.

Gradasi Sanksi Pidana yang Dijatuhkan Hakim di Pengadilan Tipikor Makassar Berdasarkan Jumlah Perkara yang Diputus Bersalah

Tahun 2011-2016

\begin{tabular}{|c|c|c|c|c|c|c|}
\hline Tahun & $\begin{array}{c}\text { Vonis } \\
\mathbf{\leq 1} \text { Th }\end{array}$ & $\begin{array}{c}\text { Vonis } \\
\mathbf{1 - 2} \text { Th }\end{array}$ & $\begin{array}{c}\text { Vonis } \\
\mathbf{2 - 5} \text { Th }\end{array}$ & $\begin{array}{c}\text { Vonis } \\
\mathbf{5 - 1 0} \text { Th }\end{array}$ & $\begin{array}{c}\text { Vonis } \\
\mathbf{\geq} \mathbf{1 0} \text { Th }\end{array}$ & Total \\
\hline 2011 & 3 & 55 & 5 & 2 & - & 65 \\
\hline 2012 & 1 & 70 & 10 & 3 & 1 & 85 \\
\hline 2013 & - & 108 & 6 & 4 & 1 & 119 \\
\hline 2014 & - & 84 & 14 & 5 & - & 103 \\
\hline 2015 & 82 & 10 & 2 & - & & 94 \\
\hline 2016 & - & - & - & - & - & - \\
\hline Total & $\mathbf{4}$ & $\mathbf{3 9 9}$ & $\mathbf{4 5}$ & $\mathbf{1 6}$ & $\mathbf{2}$ & $\mathbf{4 6 6}$ \\
\hline
\end{tabular}

Sumber: Data Sekunder Pengadilan Tipikor Makassar Tahun 2011-2016 yang diolah

Data tersebut di atas menunjukkan bahwa pengadilan Tipikor Makassar selama berdirinya yakni dari tahun 2011-2016 cenderung menjatuhkan sanksi pidana penjara terhadap terdakwa korupsi pada kategori sanksi pidana yang sangat ringan. Terdapat 403 perkara atau $86,49 \%$ dari total 466 jumlah perkara yang diputus bersalah divonis dengan sanksi pidana yang sangat ringan. Data tersebut juga menunjukkan adanya kecenderungan atau trend perkara tindak pidana korupsi divonis sangat ringan sesuai batas minimal penjatuhan pidana yang ditentukan oleh Undang-Undang Korupsi.

Banyaknya vonis bebas (tidak bersalah) serta vonis dengan sanksi pidana yang sangat ringan yang dijatuhkan oleh pengadilan Tipikor Makassar, menurut kajian ICW dimungkinkan karena sebab-sebab sebagai berikut: 1) terdakwa memang benar-benar tidak terbukti bersalah; 2) dakwaan yang disusun oleh jaksa lemah atau memang sengaja dilemahkan; 3) hakim mencari-cari pertimbangan yang menguntungkan terdakwa; atau 4) karena 
kombinasi antara dakwaan yang lemah dan hakim yang mencari-cari pertimbangan yang menguntungkan terdakwa. Tiga sebab terakhir yang paling dominan ditemui dari sejumlah putusan hakim yang menjatuhkan vonis tidak bersalah serta vonis dengan sanksi pidana yang sangat ringan terhadap para pelaku korupsi. Kondisi ini semakin diperparah akibat lemahnya pengawasan internal yang dilakukan oleh Mahkamah Agung terhadap para hakim di semua lingkungan peradilan. Pada sisi lain, keberadaan Komisi Yudisial (KY) sebagai pengawas eksternal sejauh ini kurang diperhitungkan (dan bahkan cenderung diabaikan) oleh para hakim, akibat dipangkasnya kewenangan $\mathrm{KY}$ dalam mengawasi hakim melalui putusan Mahkamah Konstitusi. ${ }^{6}$

2. Pemaknaan Korupsi oleh Hakim dan Implikasinya pada Putusan

Berdasarkan hasil studi terhadap kasus-kasus korupsi yang dipilih, dimana terdakwanya adalah para pejabat di lingkungan legislatif dan eksekutif di daerah, jenis atau bentuk korupsi yang dilakukan oleh terdakwa merupakan "perbuatan melawan hukum" dan "penyalahgunaan wewenang". ${ }^{7}$ Para hakim dalam menafsirkan makna korupsi, batas-batas, unsur-unsur dan juga vonisnya selalu mengacu dan sangat terikat pada batasan-batasan yang diberikan oleh peraturan perundang-undangan yang terkait korupsi. Kondisi seperti ini dapat dipahami, sebab dalam memeriksa perkara korupsi hakim tidak dapat berdiri sendiri. Hakim terikat pada surat dakwaan yang diajukan oleh JPU yang selalu mendakwa terdakwa dengan Pasal 2 dan 3 UUPTPK dengan berbagai variasinya. Pasal 2 dan 3 UUPTPK itu kadang-kadang ditempatkan pada posisi yang berlainan oleh JPU dalam surat dakwaan. Kedua pasal tersebut kadang-kadang yang satu didudukkan menjadi dasar dakwaan subsidair terhadap yang lain, dan kadang-kadang justru yang satu didudukkan menjadi dasar dakwaan alternatif terhadap lainnya. ${ }^{8}$

Lebih lanjut menurut Bonar Siranja, secara implisit "penyalahgunaan wewenang" inhaeren (sama) dengan melawan hukum, karena penyalahgunaan wewenang esensinya merupakan perbuatan melawan

6 Baca ICW, Catatan atas Pemantauan Perkara Korupsi yang Diputus oleh Pengadilan Tipikor selama Tahun 2008, http:// www.antikorupsi.org, diakses 18 Maret 2016.

7 Wawancara dengan Bonar Siranja, hakim pengadilan Tipikor Makassar tanggal 27 Maret 2016.

8 lbid. 
hukum. Unsur melawan hukum merupakan genus-nya, sedangkan unsur penyalahgunaan wewenang adalah spesies-nya. Meskipun penyalahgunaan wewenang dan melawan hukum inhaeren tidaklah berarti bahwa jika unsur melawan hukum dapat dibuktikan, lantas kemudian secara mutatis mutandis unsur penyalahgunaan wewenang juga terbukti. Sebaliknya, jika unsur penyalahgunaan wewenang dapat dibuktikan lantas tidak perlu membuktikan unsur melawan hukum, karena dengan sendirinya unsur tersebut telah terbukti, maka belum tentu unsur melawan hukum terbukti. ${ }^{9}$

Parameter penyalahgunaan wewenang dan melawan hukum juga perlu dibedakan. Untuk menentukan bahwa perbuatan itu termasuk penyalahgunaan wewenang perlu dibedakan antara wewenang terikat dan wewenang bebas. Pada kategori wewenang terikat untuk menilai ada tidaknya penyalahgunaan wewenang menggunakan parameter asas legalitas dan asas spesialitas, sedangkan pada kategori wewenang bebas (diskresi), parameter yang dipakai adalah asas-asas umum pemerintahan yang layak (AAUPL). ${ }^{10}$

Asas legalitas merupakan dasar legitimasi bagi pejabat pemerintah untuk bertindak untuk mencapai tujuan tertentu. Pemberian wewenang kepada pejabat pemerintah diberikan dengan sarana perundang-undangan. Penyalahgunaan wewenang terjadi jika tindakan pejabat pemerintah menyimpang dari tujuan yang telah ditentukan dalam undang-undang, ini yang dikenal dengan asas spesialitas. Asas spesialitas mengandung makna bahwa setiap kewenangan memiliki tujuan tertentu, jika disampingi akan melahirkan "detorurnamen de pouvoir". ${ }^{11}$

Kewenangan bebas (diskresi) dapat terjadi jika peraturan perundangundangan tidak mengatur kewenangan tersebut sama sekali, atau mungkin mengatur akan tetapi mengandung norma yang samar atau kabur (vage norm), atau dapat juga terjadi dalam keadaan darurat atau mendesak. Landasan filosofisnya adalah pemerintah tidak boleh berhenti sedetik pun dengan suatu alasan wewenang tersebut tidak ada landasan hukumnya. Dalam kewenangan diskresi parameter asas legalitas untuk mengukur terjadinya penyalahgunaan wewenang tidak dapat digunakan lagi, karena 
wewenang tersebut di luar wewenang yang telah ditentukan dalam peraturan perundang-undangan. ${ }^{12}$ Yang harus diterapkan adalah asas-asas umum pemerintahan yang layak, meliputi: asas kecermatan, asas persamaan, asas larangan penyalahgunaan wewenang, dan asas larangan sewenang-wenang.

Untuk membuktkan adanya unsur melawan hukum, maka parameter yang harus digunakan adalah melawan hukum secara formil dan secara materiil. Unsur melawan hukum secara formil parameter yang digunakan adalah bertentangan dengan peraturan perundang-undangan atau asas legalitas, sedangkan unsur melawan hukum secara materiil, parameter yang digunakan adalah bertentangan dengan nilai-nilai kepatutan dan nilai-nilai keadilan di dalam masyarakat.

Makna atau pengertian sifat melawan hukum formil dan sifat melawan hukum materiil lebih lanjut dapat diurai sebagai berkut: 1) sifat melawan hukum formil identik dengan melawan atau bertentangan dengan UU atau kepentingan hukum (perbuatan atau akibat) yang disebut dalam undangundang (hukum tertulis atau sumber hukum formal). Jadi, hukum diartikan sama dengan UU; 2) sifat melawan hukum materiil identik dengan melawan/bertentangan dengan hukum tidak tertulis atau hukum yang hidup, bertentangan dengan asas-asas kepatutan atau nilai-nilai (dan norma) kehidupan sosial dalam masyarakat (termasuk tata susila dan hukum kebiasaan/adat).

Kenyataan dalam praktik di pengadilan Tipikor Makassar berdasarkan hasil studi terhadap putusan perkara korupsi di lingkungan pejabat legislatif dan eksekutif di daerah, konstruksi dakwaan JPU selalu didasarkan pada Pasal 2 dan 3, baik dalam posisi dakwaan subsidaritas maupun alternatif. Demikian juga dalam menilai dan memaknai perbuatan korupsi, majelis hakim masih mencampuradukkan parameter yang digunakan untuk menguji konsep perbuatan melawan hukum dengan perbuatan menyalahgunakan wewenang.

Berdasarkan hasil studi terhadap beberapa putusan pengadilan yang dijadikan sampel penelitian, tampak adanya kecenderungan hubungan antara corak pemaknaan hakim tentang korupsi dan putusan yang dijatuhkan. Jika 
hakim menggunakan pemaknaan sempit tentang unsur-unsur tindak pidana korupsi, maka ada kecenderungan hakim menjatuhkan vonis hukuman tidak bersalah (bebas atau lepas) dan/atau jika dijatuhi vonis pidana, sanksi pidanya sangat ringan. Sebaliknya, jika hakim mengikuti pemaknaan luas tentang unsur-unsur tindak pidana korupsi yang dilakukan terdakwa, maka terdapat kecenderungan putusan bersalah (dipidana). Terhadap putusan pemidanaan ini ada yang menjatuhkan sanksinya ringandan ada yang sanksinya cukup berat.

Temuan ini dapat dimaknai bahwa kegagalan mejelis hakim membuktikan unsur-unsur tindak pidana korupsi yang didakwakan oleh JPU di persidangan, disebabkan karena hakim masih mengikuti penafsiran sempit dalam memaknai tindak pidana korupsi yang dilakukan terdakwa. Di sisi lain, jika hakim mengikuti penafsiran luas dalam memaknai tindak pidana korupsi yang dilakukan terdakwa, maka tindak pidana korupsi yang didakwakan JPU di persidangan akan berhasil dibuktikan.

Berdasarkan temuan-temuan pada analisis interpretasi dan pemaknaan hakim tentang korupsi, baik di lingkungan legislatif maupun eksekutif seperti yang telah diuraikan sebelumnya, dapatlah dibuat klasifikasi tentang karakteristik hakim dalam menafsirkan unsur-unsur korupsi. Karakteristik tersebut dapat dibagi menjadi dua klasifikasi, yakni penafsiran luas dan penafsiran sempit. Penafsiran luas adalah penafsiran yang memaknai tindak pidana korupsi secara materiil yang memasukkan unsur kepatutan dan perbuatan tercela yang bersumber dari ketentuan hukum yang tidak tertulis. Di sisi lain, penafsiran sempit adalah penafsiran yang memaknai tindak pidana korupsi hanya berdasarkan aturan perundang-undangan tertulis dan mengabaikan ketentuan hukum yang tidak tertulis.

Implikasi dari kecenderungan penggunaan kedua penafsiran tersebut, yaitu jika hakim menggunakan penafsiran sempit dalam menilai koruspi yang dilakukan terdakwa, maka ada kecenderungan melahirkan putusan tidak bersalah (bebas), dan jika pun dijatuhi vonis bersalah, maka sanksi pidananya sangat ringan. Sebaliknya, jika hakim mengikuti penafsiran yang luas dalam menilai tindak pidana korupsi yang dilakukan terdakwa, maka terdapat kecenderungan melahirkan putusan bersalah (dipidana). Terhadap putusan 
bersalah ini sanksi pidana yang dijatuhkan bervariasi, yaitu sangat ringan, ringan, sedang, berat, dan sangat berat. Namun kecenderungannya hakim di pengadilan Tipikor Makassar cenderung menjatuhkan pidana dengan kategori ringan.

Hasil studi ini dapat dimaknai bahwa kegagalan majelis hakim dalam membuktikan unsur-unsur tindak pidana korupsi yang didakwakan oleh JPU di persidangan disebabkan karena hakim masih mengikuti pemaknaan sempit tentang korupsi. Di sisi lain, jika hakim mengikuti pemaknaan luas tentang korupsi, maka tindak pidana korupsi yang didakwakan oleh JPU di persidangan akan berhasil dibuktikan. Implikasi dari kedua pemaknaan tersebut, yaitu jika hakim mengikuti pemaknaan sempit dalam menilai korupsi, maka ada kecenderungan melahirkan putusan bebas (tidak bersalah), dan jika pun dijatuhi vonis pidana, maka sanksinya relatif ringan. Sebaliknya, jika hakim mengikuti pemaknaan yang luas dalam menilai korupsi yang dilakukan terdakwa, maka terdapat kecenderungan melahirkan putusan bersalah (dipidana). Terhadap putusan bersalah ini ada yang menjatuhkan sanksi pidananya bervariasi dari yang sangat ringan, sedang, berat, dan sangat berat. Hal tersebut bergantung pada dasar-dasar pertimbangan yang dijadikan dasar oleh hakim dalam menjatuhkan putusan.

3. Refleksi Kritis Upaya Rekonstruksi Paradigma Hukum Hakim Berbasis Hukum Progresif

Refleksi kritis di sini dimaksudkan sebagai kegiatan dan perenungan mencari landasan yang kokoh untuk membangun kembali (rekonstruksi) paradigma hukum hakim dalam menangani perkara korupsi berdasarkan prinsip-prinsip hukum progresif. Belajar dari temuan-temuan studi, hukum progresif sangat penting dihadirkan untuk dijadikan dasar pijakan teoritis bagi hakim dalam menangani perkara di pengadilan. Kehadiran hukum progresif juga sangat dibutuhkan untuk menjadi alternatif solusi dan terapi dalam menyelesaikan persoalan hukum, yang pada saat ini banyak mengalami kemerosotan terutama dalam pemberantasan korupsi.

Menurut hemat penulis terdapat tiga bentuk upaya rekonstruksi yang relevan untuk ditawarkan, yaitu: pertama, rekonstruksi cara berfikir hakim yang progresif; kedua, rekonstruksi metode penafsiran hukum yang progresif; 
dan ketiga, rekonstruksi etika dalam menjalankan hukum yang progresif. Ketiga hal tersebut akan dijelaskan dalam uraian berikut.

a. Rekonstruksi Cara Berfikir Hukum yang Progresif

Rekonstruksi cara berfikir hakim yang progresif diperlukan, karena berdasarkan hasil studi ditemukan adanya kesulitan hakim dalam menangani koruspsi disebabkan karena hakim masih mengikuti cara berfikir yang positivistik. Cara berfikir ini masih diikuti secara dominan oleh para hakim di pengadilan Tipikor. Dalam pandangan positivisme hukum, hukum dikonsepkan sebagai lawyer's law, dalam arti hukum itu identik dengan undang-undang, proses hukum harus berjalan menurut prinsip "aturan dan logika" (rules and logis), dan undang-undanglah yang dianggap paling mampu menertibkan masyarakat. Pandangan ini melihat hukum sebagai suatu institusi pengaturan yang linier, mekanik, dan determenisitik terutama untuk kepentingan profesi hukum sendiri. Paham ini melihat hukum sebagai sesuatu yang rasional, logis, penuh kerapian, dan keteraturan, tegasnya hukum adalah sebuah order yang diterapkan kepada manusia dan oleh karenanya manusia harus tunduk kepadanya. ${ }^{13}$

Dalam hal ini, Wignyoesubroto menyarankan agar paradigma kerja hakim di negara-negara berkembang yang berkultur majemuk seperti Indonesia sudah waktunya berubah dan diubah. Hakim bukan lagi sebatas bereksistensi sebagai mulut yang membunyikan kalimat-kalimat undangundang (le juge est uniquenment la bauche qui prononce le most de lois). Hakim juga bukan piranti yang dirancang untuk berlogika dan bekerja secara mekanik, melainkan manusia seutuhnya yang punya kepekaan pada kemanusiaan dan kepedulian sosial. Kalaupun hakim itu harus membaca bunyi kata-kata yang tertera secara tekstual di buku undang-undang, dia pun harus pula belajar dan pandai membuat interpretasi yang tidak harfiah (konotatif), agar mampu mengungkap norma-norma sosial yang secara kontekstual melatari setiap preskripsi undang-undang. Hakim yang terdidik untuk melayani kebutuhan hukum masyarakat yang berkultur majemuk,

${ }^{13}$ Satjipto Rahardjo, Konstitusional dari Dua Sudut Pandang, Harian KOMPAS, 7 September 1998, hlm. 4. 
bukanlah kepanjangan tangan badan legislatif. Hakim yang bertugas di daerah-daerah sangat diharapkan dapat memainkan peran sebagai agen yang mampu mengantar hukum undang-undang yang diproduksi di pusat ditransformasi ke dalam suatu ekspresi kearifan dan keadilan yang bisa diterima oleh warga masyarakat setempat.

Hukum progresif mencoba membongkar cara-cara berhukum yang telah mengakar tersebut dengan kata kunci hukum untuk manusia, bukan sebaliknya manusia yang dipaksa tunduk kepada hukum. Hukum progresif adalah hukum yang membebaskan, hukum yang membahagiakan, hukum yang memuat moral kemanusiaan, dan hukum yang merupakan sebuah proses yang tidak pernah final. Hukum progresif bukan sekedar menerapkan aturan dan hanya untuk memenuhi prosedur, melainkan hukum yang harus dilihat sebagai persoalan manusia secara utuh. Hukum progresif adalah hukum yang diperlukan untuk manusia, baik dalam aksiinteraksi sesama manusia maupun manusia dengan alam semesta, yaitu lingkungan sosial dan alam sekitarnya. Hukum progresif adalah hukum yang pada hakikatnya mengatur perilaku manusia melalui norma-norma hukum yang diciptakan yang lebih mengutamakan keadilan dan kebahagiaan yang hakiki bagi kehidupan. ${ }^{14}$

b. Rekonstruksi Penafsiran Hukum yang Progresif

Hasil penelitian menunjukkan adanya pola hubungan antara karakteristik pemaknaan hakim tentang korupsi dan vonis yang dijatuhkan. Jika hakim mengikuti pemaknaan sempit tentang korupsi, maka ada kecenderungan putusan yang dijatuhkan bebas (tidak bersalah) dan, atau jika terdakwa dijatuhi vonis pidana, sanksinya yang relatif ringan. Sebaliknya, jika hakim mengikuti pemaknaan luas tentang korupsi, maka terdapat kecenderungan putusan yang dijatuhkan kepada terdakwa korupsi adalah vonis bersalah (dipidana). Pemaknaan sempit dan luas tentang korupsi didasarkan pada jenis korupsi yang berupa "perbuatan melawan hukum" dan "penyalahgunaan wewenang" yang dilakukan terdakwa. Pemaknaan sempit tentang korupsi didasarkan pada kriteria perbuatan 
melawan hukum dan penyalahgunaan wewenang yang hanya melanggar peraturan perundang-undangan tertulis, sedangkan pemaknaan luas didasarkan di samping melanggar peraturan perundang-undangan yang tertulis juga melanggar aturan yang tidak tertulis. Pelanggaran peraturan yang tidak tertulis berupa perbuatan yang tidak patut, tercela, dan bertentangan dengan asas-asas keadilan di masyarakat untuk unsur "perbuatan melawan hukum", sedangkan yang tidak tertulis dari unsur "penyalahgunaan wewenang" berupa pelanggaran terhadap asas-asas umum pemerintahan yang layak (AAUPL).

Hasil studi menunjukkan, bahwa kegagalan majelis hakim membuktikan unsur-unsur tindak pidana korupsi yang didakwakan oleh JPU di persidangan disebabkan oleh karena hakim masih mengikuti pemaknaan sempit tentang korupsi. Di sisi lain, jika hakim mengikuti pemaknaan yang luas, maka tindak pidana korupsi yang didakwakan oleh JPU di persidangan berhasil dibuktikan. Implikasi dari kedua pemaknaan tersebut adalah jika hakim mengikuti pemaknaan sempit dalam menilai korupsi yang dilakukan terdakwa, maka ada kecenderungan melahirkan putusan bebas (tidak bersalah) dan jika pun dijatuhi vonis pidana, sanksinya sangat ringan. Sebaliknya, jika hakim mengikuti pemaknaan yang luas dalam menilai korupsi yang dilakukan terdakwa, maka terdapat kecenderungan melahirkan putusan bersalah (dipidana). Terhadap putusan bersalah ini ada yang menjatuhkan sanksi pidana bervariasi dari yang sangat ringan, sedang, dan berat. Hal tersebut bergantung pada dasar-dasar pertimbangan yang dijadikan dasar oleh hakim dalam menjatuhkan vonis.

Bertolak dari hasil studi tersebut, sangat relevan dihadirkan hukum progresif sebagai dasar melakukan rekonstruksi terhadap cara penafsiran hukum oleh hakim dalam menangani perkara. Hukum progresif menghendaki adanya penafsiran yang holistik (luas) atas penyelesaian permasalahan hukum, sehingga akan terwujud keadilan subtantif dan tidak sekedar mengejar keadilan formal-prosedural belaka. Penafsiran adalah pemberian makna terhadap teks peraturan dan fakta-fakta dan tidak berhenti hanya pada pembacaan harfiah teks dan fakta-fakta tersebut. Ini yang disebut cara penafsiran hukum progresif, yaitu menempatkan 
teks/fakta dalam sebuah konteks tertentu dan kemudian dilakukan kontekstualisasi.

Penafsiran progresif menundukkan rumusan peraturan pada posisi sebagai eksemplar awal, sedangkan yang ingin dijangkau adalah suatu makna yang lebih dalam lagi, yakni keadilan. Dengan demikian, posisi awal dibuatnya hukum tertulis bukan hal yang bersifat final dan mutlak. Peraturan hanya mengingatkan, dalam masyarakat harus ada keadilan dan keadilan itu kemudian dirumuskan dalam bentuk-bentuk kata-kata rumusan hukum. Keadilan baru merupakan satu hal, karena masih ada hal yang lain seperti, kemanfaatan (utility), dan kepastian (billickheid). Dengan kata lain, setiap kali membaca peraturan maka setiap kali pula harus dicari makna lebih dalam yang ada di belakang peraturan tersebut. ${ }^{15}$

c. Rekonstruksi Etika Profesi Hakim yang Progresif

Rekonstruksi etika profesi hakim yang progresif sangat penting untuk dilakukan. Hal ini didasarkan pada hasil studi/penelitian, bahwa proses menangani suatu perkara oleh hakim di pengadilan Tipikor Makassar tidak semata-mata urusan teknis yuridis, akan tetapi melibatkan unsur-unsur etika dalam menjalankan hukum. Unsur etik ini terkait dengan orientasi dan motivasi hakim dalam menjalankan hukum. Seorang hakim dalam menangani suatu perkara, tidak dapat terlepas dari orientasi dan motivasi yang terdapat dalam dirinya. Orientasi dan motivasi ini dapat berbeda-beda antara hakim yang satu dan hakim yang lainnya, meskipun dalam tataran normatif terdapat standar dan patokan yang sama (code of conduct). Hal ini dapat terjadi karena setiap hakim pada hakikatnya adalah manusia biasa yang di dalam dirinya terdapat nafsu dan kepentingan yang berbeda-beda. Nafsu dan kepentingan itulah yang ikut mewarnai orientasi hakim dalam menangani suat perkara.

Berkaca dari hasil studi ini, maka orientasi dan motivasi hakim dalam menangani suatu perkara sangat menentukan kualitas produk putusan hakim (output) yang dijatuhkan kepada terdakwa. Jika hakim sangat berpegang teguh pada nilai-nilai ideal hukum maka putusan akan menjadi

15 Satijipto Rahardjo, Penafsiran Hukum Progresif, Makalah bahan bacaan pada Program Doktor IImu Hukum Undip, 2007. 
lebih berkualitas, dalam arti lebih dekat dengan keadilan dan kebenaran. Namun, jika terjadi pergeseran pilihan nilai-nilai ideal hukum ke nilai-nilai subjektif akan berimplikasi pada merosotnya kualitas putusan hakim, artinya putusan akan menjauhi nilai keadilan dan kebenaran.

Kondisi semacam itu yang perlu mendapatkan perhatian dan kontrol, karena memang demikian realitanya. Menurut Rahardjo, hukum akan ditegakkan (enforced) menurut perilaku orang yang menjalankannya. Sistem hukum yang dipakai oleh bangsa-bangsa boleh sama, tetapi hasil kerjanya bisa berbeda dan itu semua disebabkan oleh masuknya unsur perilaku. Disebabkan unsur perilaku ini menjadi faktor penentu, maka unsur "semangat" dalam menjalankan hukum juga menjadi sesuatu yang penting. Menurut Rahardjo, yang sangat penting dalam pemerintahan dan dalam hal hidupnya negara adalah semangat, semangat penyelenggara negara, semangat para pemimpin pemerintahan.

Hal senada dikemukakan oleh Antonius Sujata, bahwa mencari keadilan itu selain dibutuhkan keterampilan juga perlu dibarengi oleh kegigihan. Bahkan lebih dari itu, juga sangat diperlukan kemampuan untuk mendengarkan serta memenuhi jeritan keadilan masyarakat, agar putusanputusan yang diambil tidak bersifat subjektif serta kontra produktif. ${ }^{16}$

Menurut Mahfud M.D., terdapat dua prasyarat utama yang harus dimiliki oleh para aktor penegak hukum dan pejabat lain untuk memperbaiki keadaan yang bebas dari korupsi, kolusi, dan nepotisme (KKN), yaitu "bersih dan berani". Bersih, artinya bermoral, punya track record (rekam jejak), tidak pernah korup dan tidak mempunyai masalah dengan hukum. Berani, artinya mempunyai nyali untuk bertindak terhadap siapa pun guna mendobrak kejumudan birokrasi. Bersih dan berani merupakan prasyarat kumulatif, sebab jika hanya bersih tetapi tidak berani, maka akan selalu gamang. Akan tetapi, jika hanya berani tetapi tidak bersih, bisa-bisa justru menjadi pemutih untuk menghilangkan jejak kasus, pencipta KKN baru, atau tiba-tiba kehilangan keberanian karena dihantui ketidakbersihannya.

${ }^{16}$ Antonius Sujata, 2000, Reformasi dalam Penegakan Hukum, Dịambatan, Jakarta, hlm. 132. 
Keterampilan merupakan syarat tambahan berikut yang dapat dibangun menyusul prasyarat bersih dan berani. ${ }^{17}$

Mengacu pada pendapat Rahardjo, Sujata, dan Mahfud di atas, maka strategi yang perlu dilakukan dalam upaya rekonstruksi ini adalah perlunya membangun faktor perilaku, semangat, diri yang bersih, serta keberanian hakim dalam menangani perkara. Hakim harus mempunyai orientasi nilai yang benar dalam menangani perkara serta tidak ikut hanyut pada perilaku korup dalam peradilan (judicial corruption).

Di sinilah arti penting kehadiran hukum progresif, dengan semboyan hukum yang pro-keadilan dan hukum yang pro-rakyat. Hukum progresif menempatkan dedikasi para pelaku (aktor) hukum di garda terdepan dalam penegakan hukum. Para pelaku hukum dituntut mengedepankan kejujuran dan ketulusan dalam menjalankan hukum. Mereka harus mempunyai empati dan kepedulian terhadap penderitaan yang dialami rakyat dan bangsa ini. Kepentingan rakyat (kesejahteraan dan kebahagiaan) harus menjadi titik orientasi dan tujuan akhir penyelenggaraan hukum. Dalam hukum progresif, proses perubahan tidak lagi berpusat pada peraturan, akan tetapi pada kreatifitas pelaku hukum mengaktualisasikan hukum dalam ruang dan waktu yang tepat. Para pelaku hukum progresif dapat melakukan perubahan dengan melakukan pemaknaan yang kreatif terhadap peraturan yang ada, tanpa harus menunggu berubah atau diubahnya peraturan. Peraturan yang buruk tidak harus menjadi penghalang bagi para pelaku hukum progresif untuk menghadirkan keadilan bagi rakyat dan pencari keadilan, karena mereka dapat melakukan interpretasi secara baru setiap kali terhadap suatu peraturan.

\section{KESIMPULAN}

Berangkat dari uraian dan pembahasan yang telah dipaparkan sebelumnya, maka penelitian ini dapat ditarik kesimpulan bahwa Berdasarkan hasil studi ditemukan bahwa dalam praktik di pengadilan Tipikor Makassar, paradigma hukum hakim dengan karakter positivistik masih mendominasi paradigma hakim

17 Moh. Mahfud M.D, 2007, Hukum tak Kunjung Tegak, PT. Citra Aditya Bakti, Bandung, hlm. 81. 
dalam menafsirkan ketentuan perundang-undangan. Implikasinya banyak kasus korupsi yang diajukan ke pengadilan Tipikor Makassar diputus bebas dan dijatuhi sanksi pidana yang relatif ringan.

Proses rekonstruksi paradigma hukum hakim dapat dilakukan dengan cara nilai-nilai paradigma hukum lama perlu dikritisi, diperbarui, dan/atau diganti dengan nilai-nilai paradigma hukum baru yang progresif dan responsif. Rekonstruksi tersebut dapat meliputi: (i) rekonstruksi cara berfikir hukum yang progresif; (ii) rekonstruksi metode penafsiran hukum yang progresif; dan (iii) rekonstruksi etika profesi hakim yang progresif dalam menjalankan hukum.

\section{DAFTAR PUSTAKA}

\section{Buku}

Djaja, Ermansyah, 2010, Meredesain Pengadilan Tipikor: Implikasi Putusan MK No. 012-016-019/PPU-IV/2006, Sinar Grafika, Jakarta.

Irfan, M. Nurul, 2011, Korupsi dalam Hukum Pidana Islam, Amzah, Jakarta.

Mahfud M.D, Moh., 2007, Hukum tak Kunjung Tegak, PT. Citra Aditya Bakti, Bandung.

Miles, Mattew B. dan A. Michael Haberman. 1999, Analisis Data Kualitatif, UI Press, Jakarta.

Rahardjo, Sajipto, 1980, Hukum dan Masyarakat, Angkasa, Bandung.

Sujata, Antonius, 2000, Reformasi dalam Penegakan Hukum, Djambatan, Jakarta.

\section{Sumber Lain}

ICW. Catatan atas Pemantauan Perkara Korupsi yang Diputus oleh Pengadilan Tipikor selama Tahun 2008, http://www.antikorupsi.org, diakses 18 Maret 2016.

Jayadi, Ahkam, Hakim, Wakil Tuhan di Muka Bumi, Harian Fajar, 20 Juli 2011.

Rahardjo, Sajipto, Konstitusional dari Dua Sudut Pandang, Harian KOMPAS, 7 September 1998.

, 2007, Penafsiran Hukum Progresif, Makalah bahan bacaan pada Program Doktor Ilmu Hukum Undip. 